Late Cenozoic Paleoceanography of the Central Arctic Ocean

This article has been downloaded from IOPscience. Please scroll down to see the full text article.

2011 IOP Conf. Ser.: Earth Environ. Sci. 14012002

(http://iopscience.iop.org/1755-1315/14/1/012002)

View the table of contents for this issue, or go to the journal homepage for more

Download details:

IP Address: 217.44.53.231

The article was downloaded on 30/05/2011 at 09:36

Please note that terms and conditions apply. 


\title{
Late Cenozoic Paleoceanography of the Central Arctic Ocean
}

\author{
Matt O'Regan 1,2 \\ ${ }^{1}$ School of Earth and Ocean Sciences, Cardiff University, Main Building, Park Place, \\ Cardiff, CF10 3AT, Wales, UK \\ ${ }^{2}$ Department of Geological Sciences, Stockholm University, SE-106 91, Stockholm \\ Sweden \\ E-mail: oreganM1@ cardiff.ac.uk
}

\begin{abstract}
The Arctic Ocean is the smallest and perhaps least accessible of the worlds oceans. It occupies only $26 \%$ of the global ocean area, and less than $10 \%$ of its volume [1]. However, it exerts a disproportionately large influence on the global climate system through a complex set of positive and negative feedback mechanisms directly or indirectly related to terrestrial ice and snow cover and sea ice. Increasingly, the northern high latitude cryosphere is seen as an exceptionally fragile part of the global climate system, a fact exemplified by observed reductions in sea ice extent during the past decades [2]. The paleoceanographic evolution of the Arctic Ocean can provide important insights into the physical forcing mechanisms that affect the form, intensity and permanence of ice in the high Arctic, and its sensitivity to these mechanisms in vastly different climate states of the past. However, marine records capturing the late Cenozoic paleoceanography of the Arctic are limited - most notably because only a single deep borehole exists from the central parts of this Ocean. This paper reviews the principal late Cenozoic (Neogene/Quaternary) results from the Arctic Coring Expedition to the Lomonosov Ridge and in light of recent data and observations on modern sea ice, outlines emerging questions related to three main themes: 1) the establishment of the 'modern' Arctic Ocean and the opening of the Fram Strait 2) the inception of perennial sea ice 3) The Quaternary intensification of Northern Hemisphere glaciations.
\end{abstract}

\section{Introduction}

The projected disappearance of perennial sea ice in the Arctic Ocean is one of the most alarming and immediately realized impacts of continued global warming [3]. Considerable uncertainty remains in the anticipated timing for this transition under future $\mathrm{CO}_{2}$ emission scenarios [4]. Multi-model ensemble mean estimates under 'business as usual' scenarios in the IPCC 4th Assessment Report, indicate that perennial sea ice may disappear anywhere from 2050 to well beyond 2100, corresponding to atmospheric $\mathrm{CO}_{2}$ levels of 520 to $>700 \mathrm{ppmv}$ [4]. However, the rate of sea ice reduction derived from satellite observations during the past decade is not captured in these models, suggesting that enhanced sensitivity of sea ice to the feedback mechanisms that amplify global temperature change in the Arctic may remain poorly understood and paramaterized $[5,6]$.

One of the most illustrative examples of sea ice sensitivity to global climate change was presented by Johannessen [7], by comparing the satellite derived annual sea ice extent from 1979-2007 against atmospheric $\mathrm{CO}_{2}$ concentrations during the same time period (Figure 1). The strong linear correlation between these datasets was used to forecast the sea ice extent up until 2050, and illustrated that the corresponding predictions are several million $\mathrm{km}^{2}$ lower than IPCC ensemble mean predictions. 
On geologic timescales, the sensitivity of the Arctic to climate change was recently quantified through a comparison of reconstructed Arctic and average Northern Hemisphere (NH) summer temperatures during four periods in the last 3 Million years (the Holocene thermal maximum, the last glacial maximum, the last interglacial and the midPliocene). The results illustrate that Arctic temperature anomalies are amplified by a factor of 3-4 above the $\mathrm{NH}$ average during periods when the global climate cools and warms [6]. However, we still lack a complementary understanding of the variability of sea ice in the geologic past, or how the mechanisms that control it have changed. The striking correlation between sea ice extent and atmospheric $\mathrm{CO}_{2}$ in Figure (1), and the apparently predictable amplification of temperature change in the Arctic, raise questions about how useful these relationships are for hind-casting when large-scale boundary conditions are altered (Figure 2)

In addition to elevated (yet poorly constrained) $\mathrm{CO}_{2}$ concentrations in the Cenozoic, these boundary conditions include changes in the freshwater budget, and exchange with both the Pacific and Atlantic Oceans. These changes clearly modify atmospheric and oceanic circulation patterns and impact the vertical stratification and overall heat budget of the Arctic. Similarly, the advance and retreat of large ice sheets alter regional temperature and circulation patterns and have certainly changed dramatically through the late Cenozoic. An understanding of how these boundary conditions have influenced the form, intensity and permanence of ice cover in the Arctic can help improve our understanding of the complex modern oceanatmosphere-ice system and how it has evolved with global climate. It is also needed to define natural variability within this system and identify periods in the geologic past that may serve as potential analogues for future climate states. As it is the oceanic response that is of greatest concern, these insights must come from the analysis of marine sediments

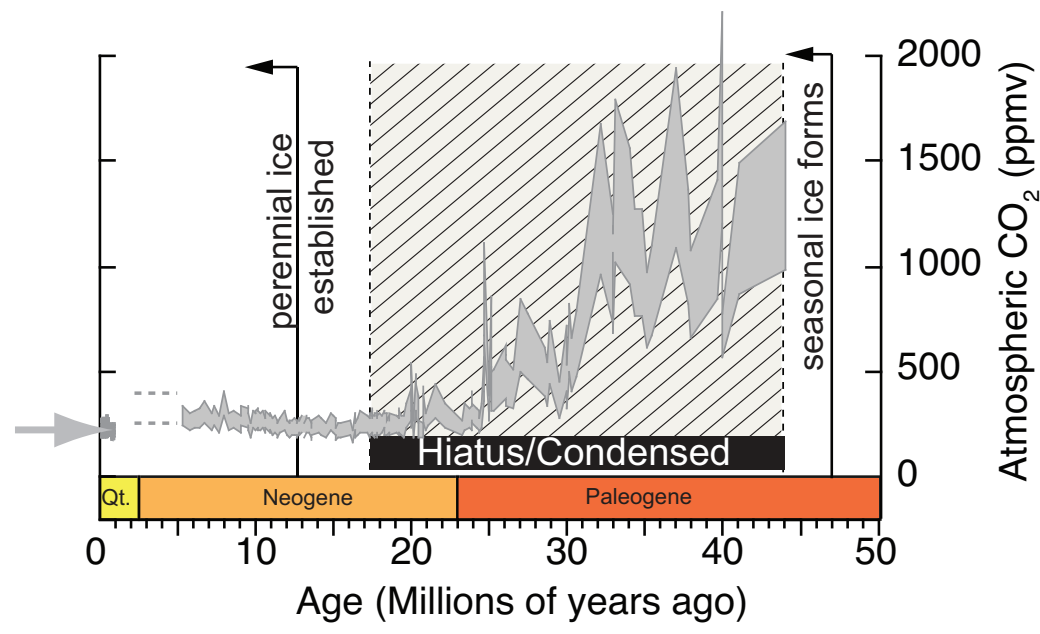

Figure 2. Cenozoic reconstruction of atmospheric carbon dioxide concentration from marine proxy records [9]. Grey arrow on left indicates pre-industrial $\mathrm{CO}_{2}$. Results from the Arctic Coring Expedition on the Lomonosov Ridge indicate that seasonal sea ice was established around 47 $\mathrm{Ma}$, when greenhouse gas concentrations were comparable to levels at $2-4 \mathrm{x}$ the modern. ACES results also suggest the formation of perennial sea ice in the Miocene, coincident with or prior to the Middle Miocene Climate Optimum (See section 4). (. Quaternary (Qt). *It is important to note that ongoing debates exist about the actual magnitude and variability of $\mathrm{CO}_{2}$ through the Cenozoic 


\section{Coring and drilling in the Arctic}

It was only in 1991 that the first non-nuclear powered icebreakers (the Swedish $R / V$ Oden and German $R / V$ Polarstern) reached the North Pole. Since this time, hundreds of cores were retrieved from the central Arctic Ocean and its Marginal seas, adding considerably to the inventory of cores collected in previous decades, many of which from floating ice camps (Figure 3). Difficulties in dating these sediments, and the short nature of the recovered sequences (generally less than 10-15 m) has limited our ability to characterize paleoceanographic changes occurring before the last 200-300 thousand years and address the long-term stability of sea ice under different orbital, climatic and tectonic boundary conditions.

In general terms, difficulties in dating arise from the often microfossil poor glaciomarine nature of

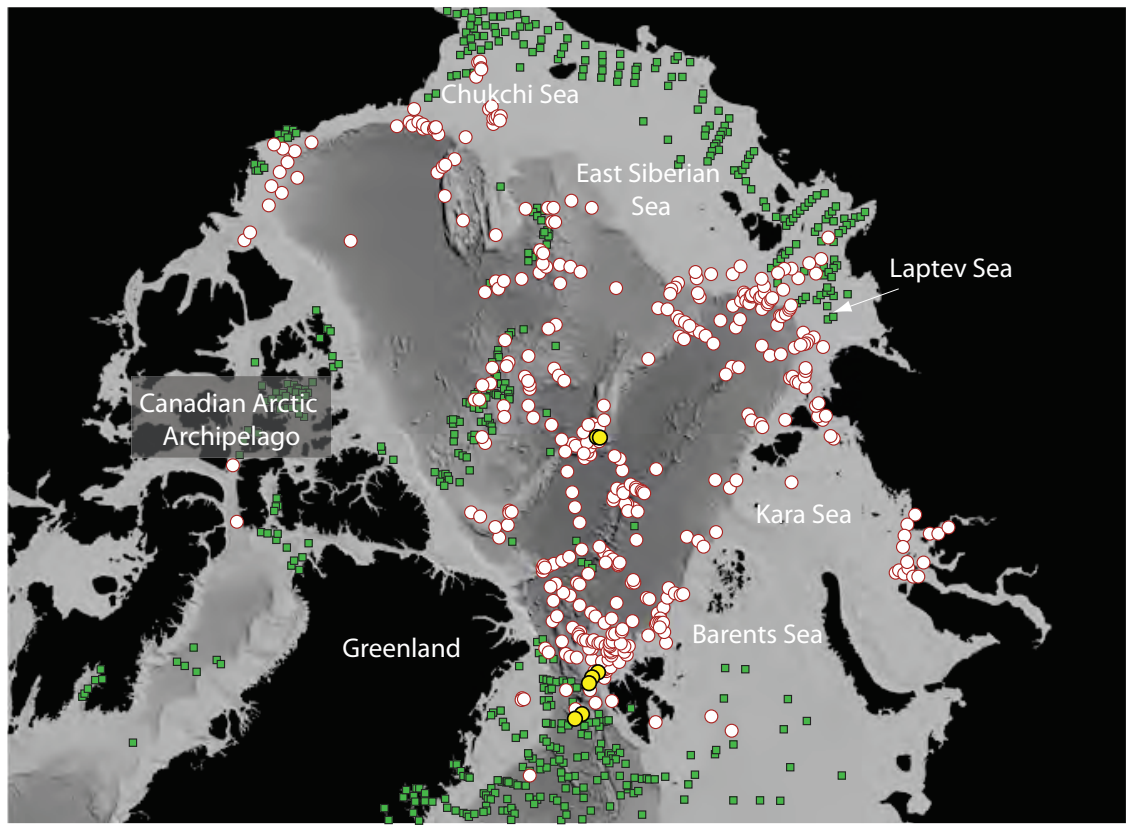

Figure 3. Partial inventory of gravity and piston cores from the Arctic Ocean. Green squares = data downloaded from wwwgeomapapporg. Red circles = compiled data from icebreaker led expeditions in the past 20 years. Yellow circles $=$ ODP/IODP boreholes Detailed data from the analysis of many of these cores can be found at wwwpangaeade. For color reporductions of this and other figures, the reader is referred to the online version of this article. the sediments, and is compounded by a complex downhole paleomagnetic signal that has yet to be integrated with the global geomagnetic timescale. These problems are generally not as severe in marginal settings of the Arctic Ocean. Similar challenges are faced when attempting to derive proxies for past sea ice conditions, and many established and emerging proxies, including microfossil based transfer functions [10], abundances [11] and organic biomarkers [12] have yet to be successfully applied in central Arctic Ocean sediments.

An important realization for anyone studying the $\begin{array}{llllllllllll}\mathrm{C} & \mathrm{e} & \mathrm{n} & \mathrm{O} & \mathrm{z} & \mathrm{O} & \mathrm{i} & \mathrm{c}\end{array}$

paleoceanography of the Arctic, is that while absolute and relative ages remain difficult to determine, correlating depositional sequences between cores and across relatively large spatial distances is possible using continuous downhole records of the lithologic, magnetic, and physical properties of the sediments and their microfaunal composition [13]. Depending on how robust the stratigraphic correlation is, this approach can be used to identify syndepositional sediments and combine age markers derived from different cores (Figure 4). Although not yet exploited, these correlations can also be used to investigate changes in the vertical water mass properties on glacial/interglacial timescales without needing a detailed or finely tuned age-model (Figure 4).

Despite the continued advance of our knowledge on late Quaternary paleoceanography in the Arctic (see [19] for a detailed overview), the largest contribution to our emerging understanding of late Cenozoic Arctic Paleoceaonography came from the Integrated Ocean Drilling Program's pioneering Arctic Coring Expedition (ACEX). This expedition not only recovered the first Cenozoic marine 

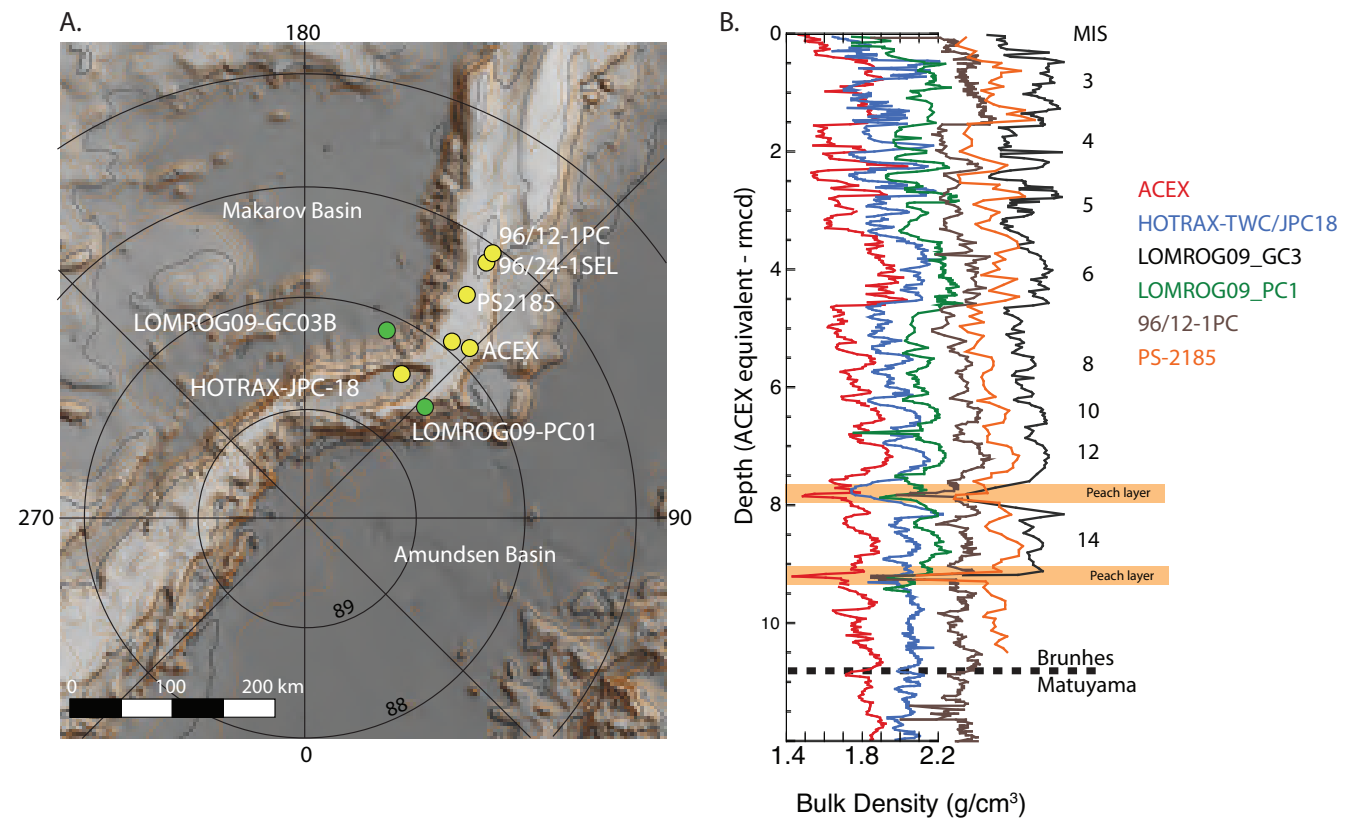

Figure 4. A. Bathymetric map of the central Lomonosov Ridge [14] showing the location of six cores collected from varying water depths (Table 1) that can be stratigraphically correlated without prior knowledge on the age of the sediments. B. Stratigraphic correlation of the six cores illustrated using downhole bulk density profiles. The cores are migrated onto the ACEX depth scale using prominent tie points. Inferred ages are from compiled relative and absolute dating techniques applied to the different records and covering MIS 1-6 (Table 1), with older ages derived from cyclostratigraphic analysis of the ACEX record [13]. C. A number of different chronostratigraphic techniques were applied to these cores to acquire ages for sediments during the last $200 \mathrm{Kyr}$. These are illsutrated and color-coded to show which core they were derived from (Table 1). While some scatter still exists, there is overall agreement between the different chronostratigraphic methods back to the end of MIS5. The detail of the stratigraphic correlation from $\mathbf{B}$ is shown on the right using grain size records for the upper $6 \mathrm{~m}$ of the migrated depth scale.

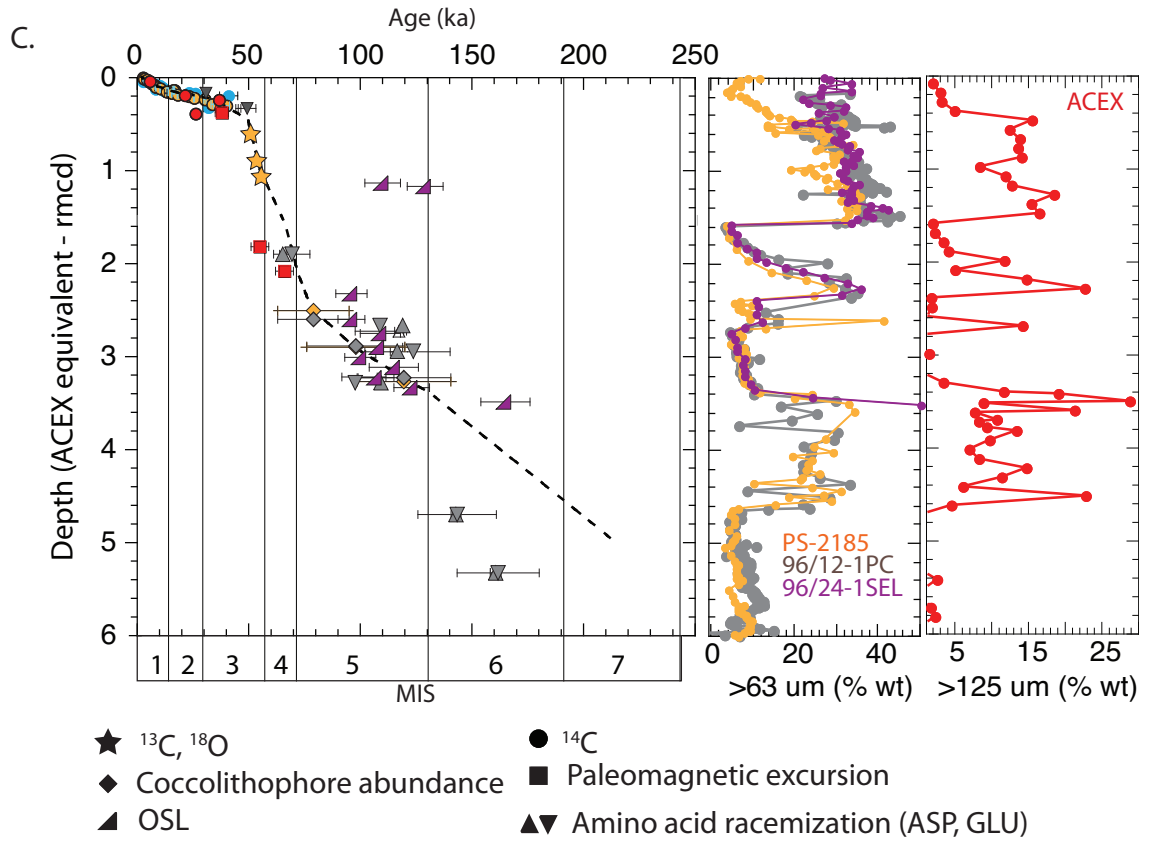


sediments sequence from the central Arctic Ocean, but illustrated that drilling was possible in the continuously moving ice pack, there-by opening the way for future scientific drilling [20]. ACEX targeted 4 closely spaced sites on the circumpolar region of the Lomonosov Ridge Collectively, a 428meter sequence of Cenozoic sediments was penetrated and partially recovered, reflecting deposition during the subsidence and drift of the Lomonosov Ridge towards its present position [21]. Many of the traditional limitations to dating Arctic sediments, namely the sporadic and low occurrence of microfossils and a complex magnetostratigraphy, were also encountered in the $\sim 198 \mathrm{~m}$ late Cenozoic section of the ACEX record. To overcome these limitations a few key biostratigraphic datums were used in conjunction with beryllium isotopes and partially supported through cyclostratigraphic analysis [22] (Figure 5).

Table 1. Locations, modern water depths, methods of dating and references for cores displayed in Figure 4 $\mathrm{PM}=$ Paleomagnetic excursions; $\mathrm{cn}=$ calcareous nannofossil abundance/assemblage data; AAR=Amino Acid Racemization; OSL=Optically Stimulated Luminescence Dating; cy=cyclostratigraphy.

\begin{tabular}{|c|c|c|c|c|c|}
\hline Core & Lat & Lon & Water Depth (m) & Dating method & Reference \\
\hline$\overline{\mathrm{ACEX}}($ Holes 4C/ 3A) & 879 & $1362-1395$ & $1200-1290$ & ${ }^{14} \mathrm{C}, \mathrm{PM}, \mathrm{cy}$ & {$[15,13]$} \\
\hline 96/12-1PC & 871 & 1448 & 1003 & $\mathrm{AAR}, \mathrm{cn}, \mathrm{cy}$ & [16] \\
\hline 96/24-1SEL & 872 & 1446 & 980 & OSL & [17] \\
\hline PS-2185 & 875 & 1442 & 1052 & ${ }^{14} \mathrm{C}, \mathrm{cn},{ }^{13} \mathrm{C},{ }^{18} \mathrm{O},{ }^{10} \mathrm{Be}$ & [13] \\
\hline HOTRAX-JPC18 & 884 & 1466 & 2598 & ${ }^{14} \mathrm{C}, \mathrm{cn}$ & [18] \\
\hline LOMROG09-GC03 & 882 & 1564 & 3814 & N/A & \\
\hline LOMROG09-PC01 & 885 & 1335 & 1244 & N/A & \\
\hline
\end{tabular}

One of the surprising initial findings was the presence of a 26 million year (Myr) hiatus separating early to middle Eocene (44.4 Ma) from late early Miocene sediments (18.2 Ma), a result that had not been anticipated from pre-cruise analysis of seismic data. The location and duration of this hiatus, and the overall mid Cenozoic age model, were recently challenged by osmium isotope dates (Figure 5) [23]. Findings that potentially have large implications for our understanding of when the modern conditions were established in the Arctic, defined by ventilated bottom-water conditions and predominantly glaciomarine sediments [21].

\section{Establishment of the 'modern' Arctic}

The most dramatic paleoenvironmental change captured in the ACEX record is the shift from freshwater influenced biosiliceous and organic rich deposits of the Paleogene to fossil poor glaciomarine silty clays that occurred by at least the late early Miocene [22,24]. Based on the original ACEX age model, the timing of this change from euxinic to well-oxygenated open marine conditions was correlated to the tectonically controlled widening of the Fram Strait in the late early Miocene $(\sim 17.5 \mathrm{Ma})$, which allowed a critical two-way surface exchange between the Arctic Ocean and Norwegian Greenland Seas to commence [25].

The transition between these two states is captured in a $5.76 \mathrm{~m}$ sequence of cross-banded sediments, interpreted as representing alternating states of oxygenation [26] (Figure 5). This sequence occurs immediately above the 26 Myr hiatus. The origin of the hiatus has been ascribed to either the exposure of the ridge, which may have remained in a shallow water setting through most of the Paleogene [27], or to erosion from enhanced bottom water currents [28], potentially associated with the gradual opening of the Fram Strait [29].

Recent osmium isotope dates from the cross-banded and underlying Eocene age biosiliceous rich sediments suggest that the transition from euxinic to well-oxygenated conditions may have occurred in the late Eocene [23]. Within this new proposed stratigraphy, the cross-banded sediments are interpreted as a condensed section arising from sea-level variations during the opening of the Fram Strait. However, the early age (late Eocene -Oligocene) for a connection between the Atlantic and 
Arctic needs to be reconciled with plate tectonic reconstructions, which suggest crustal overlap between the modern Greenland and Svalbard margins during chron 13 time (33.3 Ma) [30], implying that the pre- and synrift topography in this region becomes quite critical to constrain.

Despite emerging questions over the timing and mechanism associated with this profound oceanographic change, from a lithostratigraphic perspective it marks the initiation of modern conditions in the central Arctic Ocean. These are defined by the apprent continuous deposition of glaciomarine silts and clays, with a minor but persistent sand component, and containing very limited

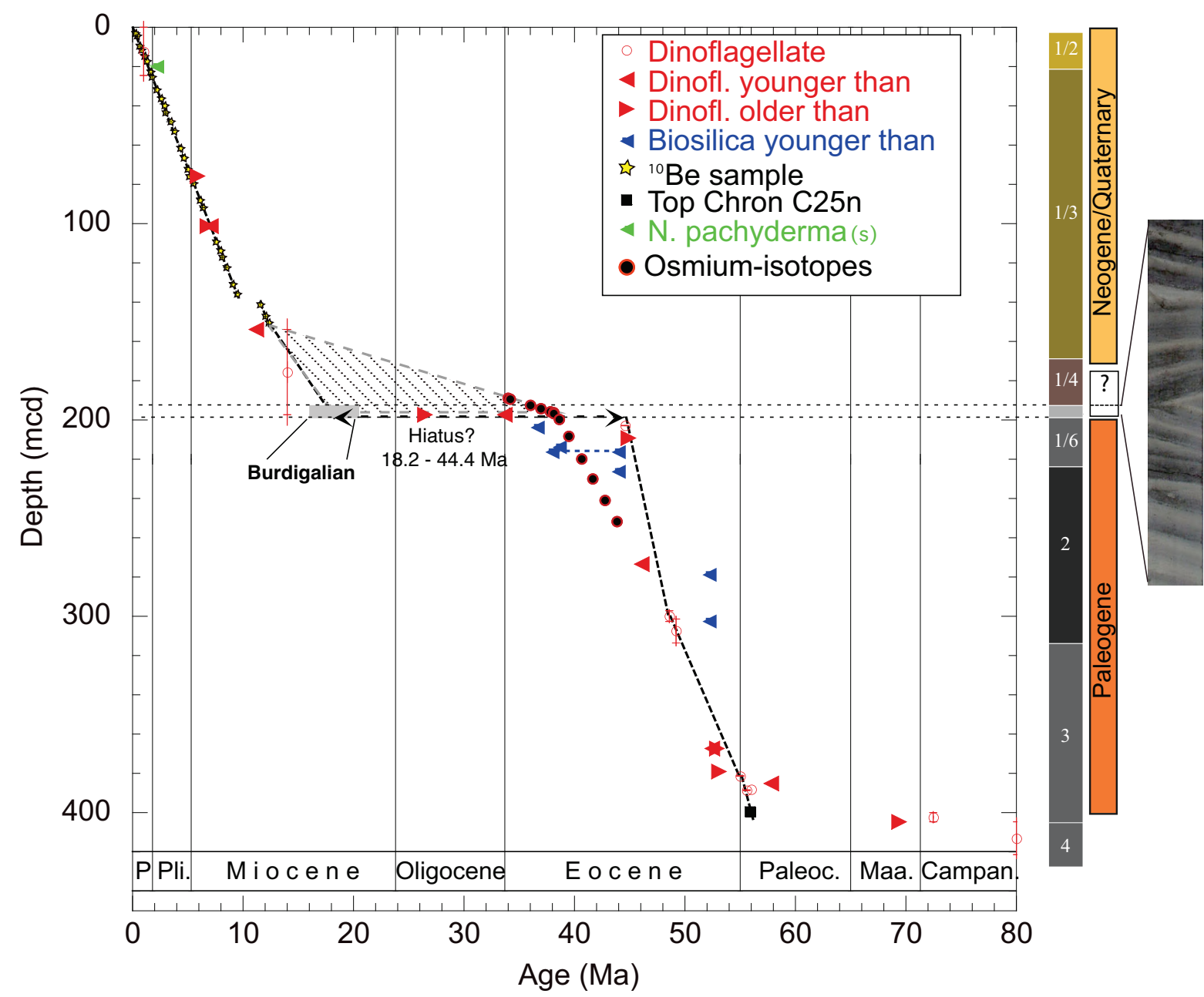

Figure 5. Age model for the ACEX record and corresponding lithologic units [22]. New osmium derived dates [23] are also shown and highlight an emerging discrepency. On the far right is an image of the cross-banded sequence that marks the transition form euxinic to oxygenated bottom water conditions

and sporadic preserved microfossils.

\section{Onset and persistence of perennial ice}

Based on the results from ACEX there is strong evidence indicating the existence of seasonal ice in the Eocene (47 Ma) [31] when global atmospheric $\mathrm{CO}_{2}$ concentrations were likely $>1000$ ppmv. While no direct proxy for perennial ice has been derived from the microfossil poor glaciomarine sediments deposited since at least the late early Miocene, novel solutions for identifying its onset were derived 
from analyzing the provenance (source region) of clay, heavy mineral and detrital iron-oxide grains found within this record $[32,33]$.

For example, Krylov et al. [32] document a pronounced shift in the clay and heavy mineral assemblages (from smectite to illite; and clinopyroxenes to hornblendes respectively) that they ascribe to a change from the Western Laptev/Kara Seas, to the East Siberian Sea as the dominant sediment source area. As the average modern drift time for sea ice to reach the central Lomonosov Ridge from the East Siberian Sea is $>1$ year [34], this change is interpreted as marking the onset of perennial ice. This transition is independently dated between 12-14 Ma [22]. Employing similar arguments, Darby [33] uses an iron oxide fingerprinting technique to match detrital iron-oxide grains to a large database of Arctic source regions, and reports a constant input of IRD from all the circum-arctic shelves in samples extending back to at least $15 \mathrm{Ma}$, again implying that perennial ice has been present throughout this time, and potentially earlier. His analysis also illustrates that tectonic reconstructions from the middle Miocene to present do not significantly alter the distances between the Lomonosov Ridge and Western Arctic and East Siberian Shelves, and cannot be used to explain the changes in sediment provenance in the ACEX record. Frank et al [35] also argue that the generally smooth but coarse resolution exponential decrease of ${ }^{10} \mathrm{Be} /{ }^{9} \mathrm{Be}$ with depth, and the low calculated flux rates of
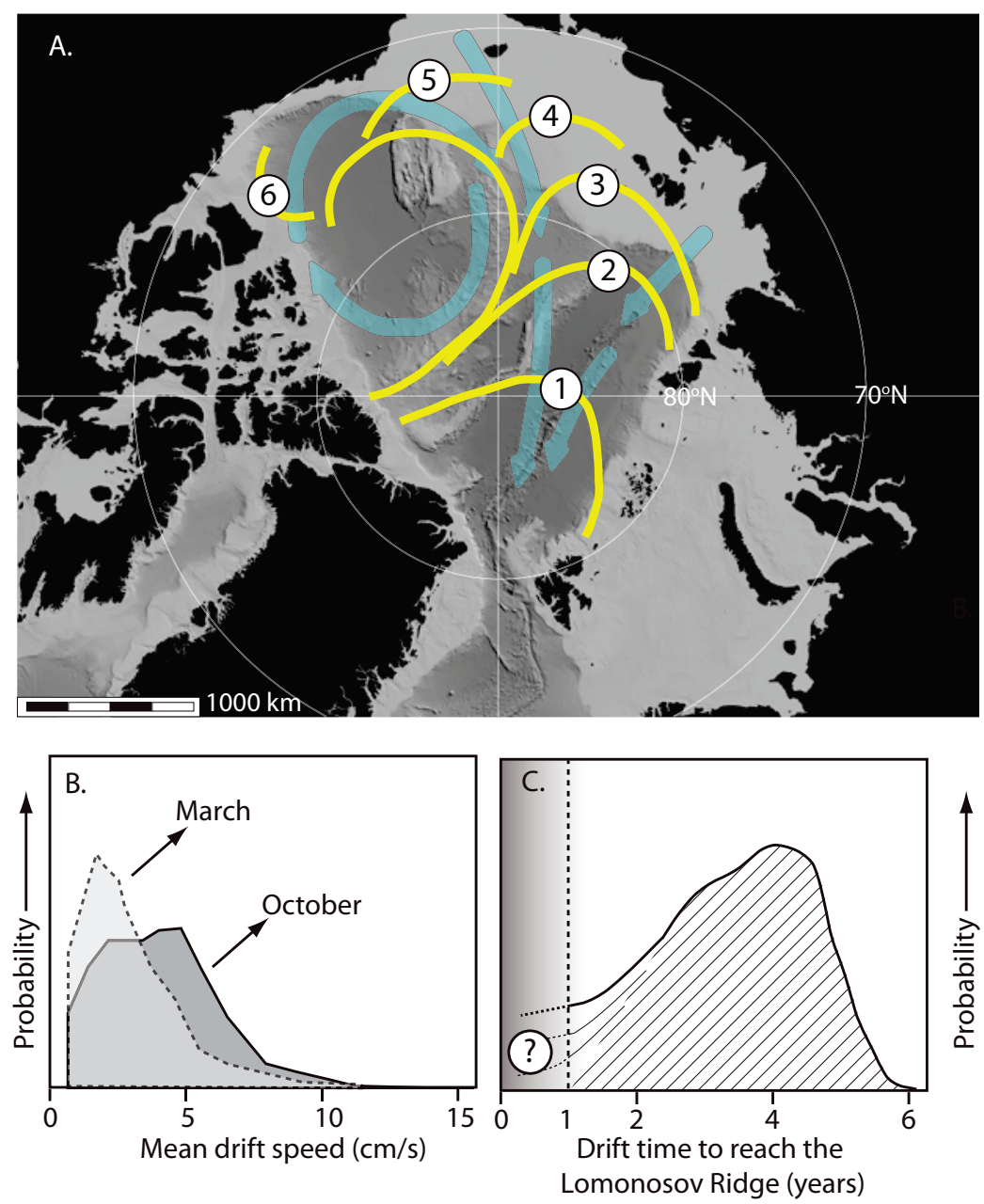

Figure 6. A. Map of the Arctic Ocean showing the dominant surface circulation patterns, and the mean drift times required for ice from different regions to exit through the Fram Strait (adapted from [34]). B. Seasonal variations in mean sea ice drift speed in the central Arctic Ocean (generalized and adapted from [44]). C. A conceptual illustration of how the mean residence time derived from the mean drift speed may not capture important variability in the statistical distribution. How probable ice drift reaching the Lomonosov Ridge in $<1$ year (marked by question mark in C) has not yet been quantified for the different source regions.

${ }^{10} \mathrm{Be}$ into the sediments, provide ancillary evidence for a persistent perennial ice pack since at least 12 Ma.

Within the resolution of the ACEX age model, the onset for perennial Arctic sea ice inferred by Krylov et al. [32] occurs at the end of the Middle Miocene Climate Optimum (MMCO, 15-17 Ma), 
during a period of recognized global cooling [36], reduction in atmospheric $\mathrm{CO}_{2}$ [37] and the expansion of the East Antarctic ice sheet [38]. It also appears, to a first order, synchronous with terrestrial evidence that documents middle Miocene cooling in the Canadian Arctic Archipelago (CAA) and throughout Alaska and the western North West Territories of Canada [37]. However, the assertion that perennial ice was established after the MMCO and persisted since this time is not consistent with the presence of mixed hardwood and deciduous forests which are preserved in the late Miocene/Pliocene Beaufort Formation of the CAA [40, 41], with early Pliocene sea surface temperature estimates as high as $18^{\circ} \mathrm{C}$ in the Fram Strait [42] or the early Pliocene peat deposits from Ellesmere Island $\left(78^{\circ} \mathrm{N}, 82^{\circ} \mathrm{W}\right)$ recording mean annual temperatures that were $\sim 19^{\circ} \mathrm{C}$ higher than today [43].

The drift-speed/provenance argument for delineating changes between seasonal and perennial sea ice is simple and somewhat elegant, yet the importance of the findings using this technique (namely that perennial sea ice has been a stable component of the central Arctic Ocean for 12-15 Ma) and the mismatch with other circum-arctic studies, requires further study. For example, [32, 33] both use mean annual residence time charts for sea ice emanating from different regions of the Arctic Ocean. The charts are based upon the monthly analysis of the mean field of sea ice motion derived from drifting buoys deployed on ice flows between 1979 and 1998 as part of the International Arctic Buoy Programme (IABP) [34] and from a paleoceanographic perspective may not capture two important aspects of the drift speed field. First, there is yet no analysis of the statistical distribution of these mean residence times, or quantification of the seasonal, inter-annual and decadal variability associated with them. Although this cannot be resolved in the low-resolution sedimentary records, it clearly defines what is averaged within any one sample over the few thousand years it represents (Figure 6).

A second obstacle is how the modern speeds would be affected by diminished sea ice thickness that would exist during warmer periods of the geologic past. Modern observations suggest a strong link between mean drift speed and sea ice thickness. This was recently illustrated using IABP data [45] in which sea ice drift speeds during the last 29 years increased by $17 \%$ /decade in the winter and $85 \% /$ decade in the summer, with no corresponding increase in the derived monthly mean wind speed. This increased drift speed was associated with contemporaneous and observed thinning of the ice pack during this time [46].

At the same time, the arguments that perennial sea ice could not have existed because of the fossilized floral remains along the CAA require a more thorough analysis of the regional climatic effects that would be expected in the Miocene. For example, much warmer than modern conditions along the Northern Greenland coast and the CAA are largely reported from Miocene paleoclimate models, and are associated with a regional anomaly arising from the absence of the Greenland icesheet [47]. In this sense, the ACEX results raise important questions on the controls and overall sensitivity of sea ice in the geologic past, and provide a framework for testing and furthering our understanding of these questions. Due to the burial depth of Miocene age sediments, addressing them fully requires additional deep boreholes from strategic locations in the Arctic.

\section{Intensification of Northern Hemisphere glaciations}

The growth of large Northern Hemisphere icesheets is widely believed to have occurred between 2.9-2.6 $\mathrm{Ma}$ and is best illustrated by compilations of global benthic $\delta^{18} \mathrm{O}$ [47] and by the gradual increase in ice rafted material (IRD) in records from high latitude settings [40,49].

During the last two glacial cycles, prominent fluxes in sand sized material to the Lomonosov Ridge (Figure $3 b$ ) are closely related to known changes in the extension of the Barents/Kara icesheet to the shelf edge [13]. These results fit with the growing awareness of glaciogenic bedforms on many topographic highs, imaged with high-resolution subbottom profiling and swath-bathymetry, which indicate the incursion of deep drafting ice ( $>900 \mathrm{~m}$ draft) into the central Arctic Ocean and collectively suggest the growth of large ice shelves in the late Quaternary [50]. 
However, while there seems to be a strong correspondence between very subtle changes in grain size and glacial/interglacial cycles through the Quaternary, the ACEX record reveals an overall decrease in the amount of IRD between $\sim 2 \mathrm{Ma}$ (an interval with poor chronostratigraphic control in the ACEX record) and the better-constrained base of Marine Isotope Stage 6 (191 ka) [51] (Figure 7, Figure 4). This reduction in coarse grained IRD cannot be explained by dilution due to higher

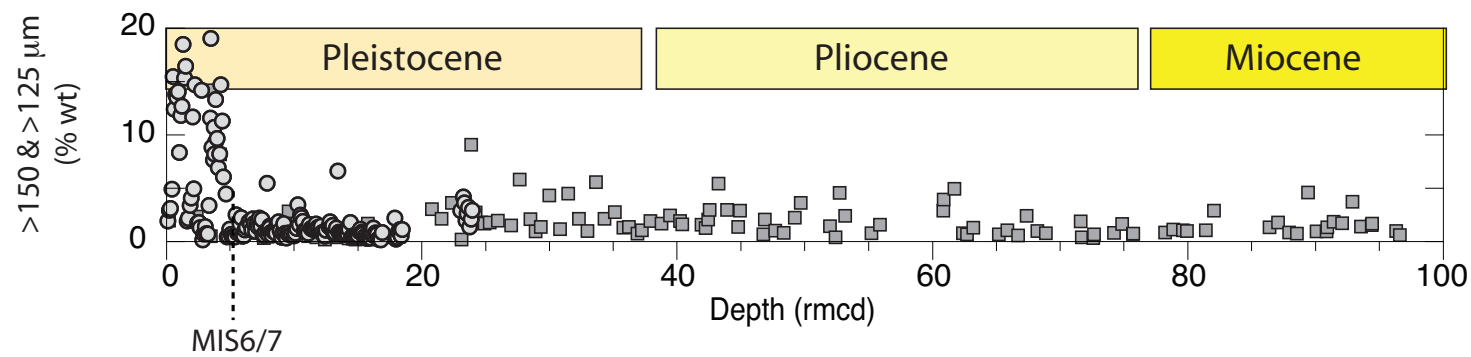

Figure 7. Coarse-fraction content of the ACEX record in the later part of the Cenozoic. $>150 \mu \mathrm{m}$ (squares) and $>125 \mu \mathrm{m}$ (circles). Boundaries of epochs derived from age model of Backman et al. [22] that uses an average sedimentation rate of $14.5 \mathrm{~m} / \mathrm{Myr}$ over this interval. Note the increase in coarse fraction content above the MIS6/7 boundary (see Figure 4 for details) and the low abundances for the middle part of the Pleistocene. No systematic increase in the coarse fraction contents is seen as NH glaciations intensified through the Pleistocene.

sedimentation rates [51], and is not consistent with patterns from other high latitude records that reveal enhanced ice rafting during the Quaternary (see compilation in [40]). Existing data from the Lomonosov Ridge indicate that episodes of intense coarse grained ice rafting occur mainly during the last two glacial cycles, which largely corresponds to the ages of dated glaciogenic bedforms [50]. These observations suggest that such massive intrusions of icebergs and ice shelves may not have occurred prior to MIS6, when IRD contents are low in the ACEX record, and furthermore suggest that sea ice was likely the dominant carrier of IRD in previous glacial periods. This remains somewhat speculative, and there is clearly evidence for large-scale ice sheet growth in the Barents Sea during the
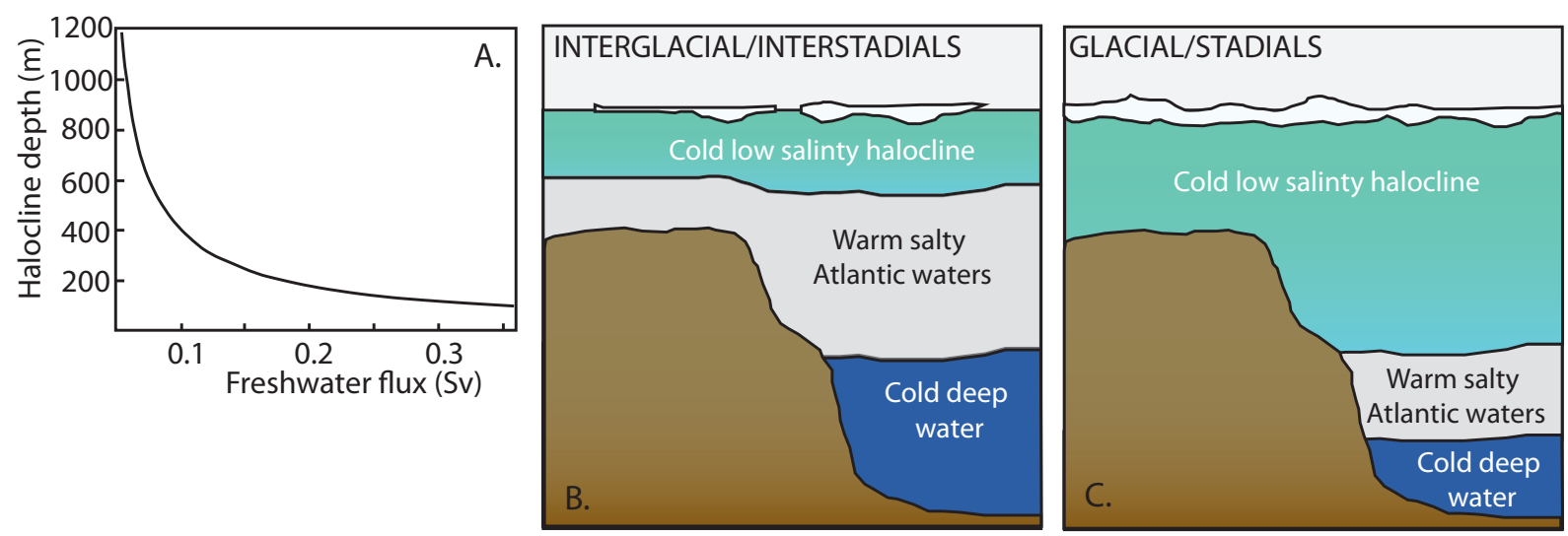

Figure 8. A. Analytically derived changes in the depth to the halocline as a function of freshwater flux to the Arctic Ocean (Jakobsson et al, 2010). B and $\mathbf{C}$ are conceptual illustrations of how the depth to the halocline (and subsequently any warm Atlantic water that enters the Arctic), may be depressed during glacial/stadial periods or at times in the geologic past when freshwater inflow to the Arctic was reduced

middle part of the Pleistocene [49,52]. Longer and better dated sequences from the Amerasian Basin, Morris Jesup Rise and other regions of the Arctic Ocean are needed to address spatial and temporal differences in depositional patterns. 
The reduction in the amount of IRD at $\sim 2 \mathrm{Ma}$ in the ACEX record coincides with the start of high amplitude oscillations in the neodynium isotopic composition of intermediate waters, which are interpreted as marking the onset of large scale Atlantic water inflow following the subsidence of the Greenland-Scotland Ridge [53]. The observed reductions in IRD that appear coincident with the enhanced inflow of Atlantic water are somewhat counter-intuitive, given the recognized influence that North Atlantic waters have on transporting heat into the central Arctic Ocean. While possible explanations for these observations may lie in the evolution of the major oceanic gateways (the Fram Strait/Barents Sea and the Bering Strait) [51], the role of changing freshwater delivery to the Arctic, long considered to be a fundamental boundary condition for sea ice growth and a possible key to Northern Hemisphere icesheet growth, remain largely unexplored. For example, Jakobsson et al. [50] illustrate how the depth of the modern halocline in the Arctic Ocean is extremely sensitive to changes in the freshwater flux, and increases sharply when freshwater delivery is reduced (Figure 8). This suggests that large-scale vertical migration of water masses may occur on glacial/interglacial timescales, and potentially during reduced/enhanced hydrologic periods of the past. To investigate these changes it is critical to exploit coupled analyses of cores that form depth transects in the modern Arctic (i.e. Figure 4b). Quantifying these changes and coupling them with proxies of past sea ice and glacial ice, would be of great benefit in attempting to reconstruct the paleoceanographic evolution of the Arctic Ocean, and how it is influenced by oceanic exchanges with the Pacific and Atlantic Oceans.

\section{Concluding remarks}

Our knowledge of past and present conditions in the Arctic Ocean is advancing rapidly, due in part to the challenge we face in improving our ability to anticipate and predict the magnitude and impacts associated with the rapidly diminishing sea ice cover. From a geologic perspective, an understanding of modern processes provides important groundtruthing for directing our studies into the past and the interpretations we extract from them. The groundbreaking Arctic Coring Expedition proved that scientific drilling in the Arctic Ocean is possible, and it is clear that more long-term records need to be recovered from the Arctic to complement and test theories that have evolved from ACEX. The overview provided here is based primarily on published results from ACEX, and attempts to highlight important questions that are emerging from these results. In doing so it admittedly overlooks many valuable contributions to our understanding of late Cenozoic paleoceanographic change in the Arctic that have emerged from other expeditions and programs. While sea ice is a dominant theme in much of this discussion, it is intimately tied with variations in both terrestrial and oceanic boundary conditions, all of which ultimately need to be integrated into a coherent picture of the geologic and paleoceanographic evolution of this Ocean, and its role in the global climate system.

\section{References}

[1] Jakobsson, M 2002 Hypsometry and volume of the Arctic Ocean and its constituent seas Geochem. Geophy. Geosy. 3 1-18

[2] Comiso J C , Parkinson C L, Gersten R and Stock L 2008 Accelerated decline in the Arctic sea ice cover Geophys Res Lett 35 doi: 101029/2007GL031972

Serreze M C, et al 2007 Perspectives on the Arctic's shrinking sea ice cover Science 315 1533-1536

[3] IPCC 2007 Climate Change 2007, The physical science basis Contribution of Working Group I to the Fourth Assessment Report of the Intergovernmental Panel on Climate Change Cambridge University Press, Cambridge and New York

[4] Zhang X and Walsh J E 2006 Toward a seasonally ice-covered Arctic Ocean: scenarios from the IPCC AR4 model simulations J. Clim. 19 1730-1747

Stroeve J, et al 2007 Arctic sea ice decline: Faster than forecast Geophys. Res. Lett. 34 L09501 doi: 101029/2007GL029703

Wang M and Overland J E 2009 A sea ice free summer Arctic within 30 years? Geophys. Res. Lett. 36 L07502 
[5] Holland M M and Bitz C M 2003 Polar amplification of climate change in coupled models Clim. Dynam. 21 221-232

[6] Miller G H, Alle R B, Brigham-Grette J, Fitzpatrick J J, Polyak L, Serreze M C, and White, J W C, 2010 Arctic amplification: can the past constrain the future? Quat. Sci. Rev. 29(15-16)1779- 1790

[7] Johannessen O M 2008 Decreasing Arctic sea ice mirrors increasing $\mathrm{CO}_{2}$ on decadal time scales Atmos. and Ocean. Sci.Lett. 1 51-56

[8] Stroeve J, and Meier W 1999 Updated current year Sea Ice Trends and Climatologies from SMMR and SSM/I, June to September 2001 Boulder, CO: National Snow and Ice Data Center Digital media

[9] Pagani M, Liu Z, LaRiviere J and Ravelo A C 2009 High Earth-system climate sensitivity determined from Pliocene carbon dioxide concentrations, Nat. Geosci. 3, 27-30

[10] de Vernal A, Hillaire-Marcel C, Solignac S, Radi T, and Rochon A 2008 Reconstructing sea ice conditions in the Arctic and sub-Arctic prior to human observations Geoph. Monograph. 180 27-45

[11] Cronin T M, Gemery L, Briggs Jr W M, Jakobsson M, Polyak L and Brouwers E M 2010 Quaternary sea-ice history in the Arctic Ocean based on new Ostracode sea-ice proxy Quat. Sci.Rev 29, 3415-3429

Nørgaard-Pedersen N, Mikkelsen N, Kristoffersen Y, 2007 Arctic Ocean record of last two glacial -interglacial cycles off North Greenland/Ellesmere Island - implications for glacial history Marine Geology 244 93-108

[12] Belt S T, Masse G, Rowland S J, Poulin M, Michel C and LeBlanc B 2007 A novel chemical fossil of palaeo sea ice: IP25 Organic Gechemistry 38 16-27

Muller J, Masse G, Stein R and Belt S T 2009 Variability of sea-ice conditions in the Fram Strait over the past 30,000 years Nat. Geosci. $2772-776$

[13] Spielhagen R F, Baumann K H, Erlenkeuser H, Nowaczyke N R, Nørgaard-Pedersen N, Vogt C and Weiel D 2004 Arctic Ocean deep-sea record of northern Eurasian ice sheet history Quat. Sci.Rev. 23 1455-1483

O'Regan M, et al. 2008 Constraints on the Pleistocene chronology of sediments from the Lomonosov Ridge Paleoceanography 23 PA1S19 doi:101029/2007PA001551

Sellén E, O’Regan M and Jakobsson M 2010 Spatial and temporal Arctic Ocean depositional regimes: a key to the evolution of ice drift and current patterns Quat.Sci.Rev.29(25-26) 3644-3664 doi:101016/jquascirev201006005

Polyak L, Bischof J, Ortiz J, Darby D, Channell J, Xuan C, Kaufman D, Lovlie R, Schneider D, Adler R, 2009 Late Quaternary stratigraphy and sedimentation patterns in the western Arctic Ocean. Global Planet. Change 68 5-17

[14] Jakobsson M, Macnab R, Mayer M, Anderson R, Edwards M, Hatzky J, Schenke H-W and Johnson P 2008 An improved bathymetric portrayal of the Arctic Ocean: Implications for ocean modeling and geological, geophysical and oceanographic analyses Geophys. Res. Lett. 35 L07602

[15] Cronin T, Eynaud F, Smith S, O'Regan M and King J 2008 Quaternary Paleoceanography of the Central Arctic based on IODP ACEX 302 Foraminiferal Assemblages Paleoceanography 23 PA1S18 doi:101029/2007PA001484

[16] Jakobsson M, Løvlie R, Al-Hanbali H, Arnold E, Backman J and Mörth M 2000 Manganese and color cycles in Arctic Ocean sediments constrain Pleistocene chronology Geology 28, 23-26

Jakobsson M, Løvlie R, Arnold E, Backman J, Polyak L, Knudsen J and Musatov E 2001

Pleistocene stratigraphy and paleoenvironmental variation from Lomonosov Ridge sediments, central Arctic Ocean Global and Planetary Change 31 1-22

Kaufman D S, Polyak L, Adler R, Channell J E T and Xuan C 2008 Dating late Quaternary planktonic foraminifer Neogloboquadrina pachyderma from the Arctic Ocean using amino acid racemization Paleoceanography 23 PA3224 doi:101029/2008PA001618

[17] Jakobsson M, Backman J, Murray and Løvlie R 2003 Optically stimulated luminescence dating supports central Arctic Ocean cm-scale sedimentation rates Geochem. Geophy. Geosy. 4(2) doi:101029/2002GC000423 
[18] Hanslik D, Jakobsson M, Backman J, Björck S, Sellén E, O'Regan M, Fornaciari E and Skog G 2010 Pleistocene Arctic Ocean sea ice and deep water isolation times Quat. Sci. Rev. 29(25-26), 3430-3441 doi:101016/jquascirev201006011

[19] Stein R 2008 Arctic Ocean Sediments: Processes, Proxies, and Paleoenvrionment (Elsevier, Amsertdam) p 592

[20] Backman J and Moran K 2009 Expanding the Cenozoic Paleoceanographic record in the Central Arctic Ocean: IODP Expedition 302 Synthesis Central European Journal of Geosciences 1(2) $157-175$

[21] Moran K, et al. 2006 The Cenozoic palaeoenvironment of the Arctic Ocean Nature 441 601-605

[22] Backman J, et al 2008 Age model and core-seismic integration for the Cenozoic Arctic Coring Expedition sediments from the Lomonosov Ridge Paleoceanography 23 PA1S03 doi: 101029/2007PA001476

[23] Poirier A and Hillaire-Marcel C 2009 Os-isotope insights into major environmental changes of the Arctic Ocean during the Cenozoic Geophys. Res. Lett. 36 L11602

[24] Stein R, Boucsein B and Meyer H 2006 Anoxia and high primary production in the Paleogene central Arctic Ocean: First detailed records from the LR Geophys. Res. Lett. 33

[25] Jakobsson M, et al. 2007 The early Miocene onset of a ventilated circulation regimen in the Arctic Ocean Nature 447 986-990 doi:101038/nature05924

[26] Sangiorgi F, et al. 2008 A 25 million year gap in the central Arctic record at the GreenhouseIcehouse transition: Looking for clues Paleoceanography 23 PA1S04 doi: 101029/2007PA001477

[27] O'Regan M, et al. 2008 Mid-Cenozoic tectonic and paleoenvironmental setting of the central Arctic Ocean, Paleoceanography 23 PA1S20 doi:101029/2007PA001559

[28] Moore T C and the Expedition 302 Scientists 2006 Sedimentation and subsidence history of the Lomonosov Ridge In Backman J, Moran K, McInroy D B, Mayer L A and the Expedition 302 Scientists Proc IODP 302: Edinburgh (Integrated Ocean Drilling Program Management International, Inc) doi:102204/iodpproc3021052006

[29] Bruvoll V, Kristoffersen Y, Coakley B J and Hopper J R 2010 Hemipelagic deposits on the Mendeleev and northwestern Alpha submarine Ridges in the Arctic Ocean: acoustic stratigraphy, depositional envrionment and an inter-ridge correlation calibrated by the ACEX results Mar.

Geophys. Res. 31 149-171 doi: 101007/s11001-010-9094-9

[30] Engen Ø, Faleide J I and Dyreng T K 2008 Opening of the Fram Strait gateway: A review of plate tectonic constraints Tectonophysics 450 51-69

[31] St John K 2008 Cenozoic ice-rafting history of the central Arctic Ocean: Terrigenous sands on the Lomonosov Ridge Paleoceanography 23 PA1S05 doi:101029/2007PA001483

Stickley C E, et al. 2009 Evidence for middle Eocene Arctic sea ice from diatoms and ice-rafted debris Nature 460 376-379 doi:101038/nature08163

[32] Krylov A A, et al. 2008 A shift in heavy and clay mineral provenance indicates a middle Miocene onset of a perennial sea ice cover in the Arctic Ocean Paleoceanography 23 PA1S06 doi: 101029/2007PA001497

[33] Darby D A 2008 Arctic perennial ice cover over the last 14 million years Paleoceanography 23 PA1S07 doi:101029/2007PA001479

[34] Rigor I G, Wallace J M and Colony R L 2002 Response of Sea Ice to the Arctic Oscillation J Climate $152648-2668$

[35] Frank M, et al. 2008 Beryllium isotopes in central Arctic Ocean sediments over the past 12 million years: Stratigraphic and paleoclimatic implications Paleoceanography 23 PA1S02 doi: 101029/2007PA001478, pp 1-12

[36] Shevenell A E, Kennett J P and Lea D W 2004 Middle Miocene Southern Ocean cooling and Antarctic cryosphere expansion Science 305 1766-1770 doi:101126/science1100061

[37] Kürschner W M, Kvacek Z and Dilcher D L 2008 The impact of Miocene atmospheric carbon dioxide fluctuations on climate and the evolution of terrestrial ecosystems $\quad$ PNAS 105(2) 449-453 
[38] Pekar S F and DeConto R M 2006 High-resolution ice-volume estimates for the early Miocene:

Evidence for a dynamic ice sheet in Antarctica Palaeogeogr. Palaeoclimatol.Palaeoecol. 231 101-109

[39] Wolfe J A 1994 An analysis of Neogene climates in Beringia Palaeogeogr. Palaeoclimatol.

Palaeoecol . 108 207-216

Fyles J G, Hills L V, Mathews Jr J V, Barendregt R W, Baker J, Irving E and Jette H 1994 Ballast Brook and Beaufort formations (Late Tertiary) on northern Banks Island, Arctic Canada Quaternary International 22/23 141-171

White J M et al. 1997 An 18-million-year record of vegetation and climate change in northwestern Canada and Alaska: tectonic and global climatic correlates Palaeogeogr. Palaeoclimatol. Palaeoecol. 130 293-306

[40] Polyak L, et al. 2010 History of sea ice in the Arctic Quat. Sci.Rev. 29(15-16) 1757-1778 doi: 101016/jquascirev201002010

[41] Miller G H, et al. 2010 Temperature and precipitation history of the Arctic Quat. Sci.Rev. 29(15-16) 1679-171

[42] Robinson M M 2009 New quantitative evidence of extreme warmth in the Pliocene Arctic Stratigraphy 6(4) $265-275$

[43] Ballantyne A P, Greenwood D R, Sinninghe Damste J S, Csank A Z, Eberle J J and Rybczynski N 2010 Singnifcantly warmer Arctic surface temperatures during the Pliocene indicated by multiple independent proxies Geology 38(7) 603-606

[44] Martin T and Gerdes R. 2007 Sea ice drift variability in Arctic Ocean Model Intercomparison Project models and observations Journal of Geophysical Research 112 C04S10

[45] Rampal P, et al. 2009 Positive trend in the mean speed and deformation rate of Arctic sea ice, 1979-2007 JGR 114 C05013

[46] Kowk R and Rothrock D A 2009 Decline in Arctic sea ice thickness from submarine and ICESat records: 1958-2008 Geophys. Res. Lett. 36 L15501 doi:101029/2009GL039035

[47] Steppuhn A, Micheels A, Bruch A A, Uhl D, Utescher T and Mosbrugger V 2007 The sensitivity of ECHAM4/ML to a double CO2 scenario for the Late Miocene and the comparison to terrestrial proxy data Global and Planetary Change 57 189-212

Tong J A, You Y, Muller R D and Seton M 2009 Climate model sensitivity to atmospheric CO2 concentrations for the Middle Miocene Global and Planetary Change 67(3-4) 129-140 You Y, Huber M, Muller R D, Poulsen C J and Ribbe J 2009 Simulation of the Middle Miocene Climate Optimum Geophys. Res. Lett. 36 L04702 doi:101029/2008GL036571

[48] Lisiecki LE and Raymo M E 2005 A Pliocene-Pleistocene stack of 57 globally distributed benthic

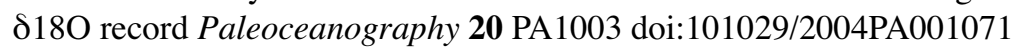

[49] Knies J, et al. 2009 The Plio-Pleistocene glaciation of the Barents Sea-Svalbard region: a new model based on revised chronostratigraphy Quat. Sci, Rev. 28(9-10) 812-829

[50] Jakobsson M, et al. 2010 An Arctic Ocean iceshelf during MIS 6 constrained by new geophysical and geological data Quat.Sci.Rev. 29(25-26) 3505-3517 doi:101016/ jquascirev201003015

[51] O'Regan M, St John K, Moran K, Backman K, King J, Haley B A, Jakobsson M, Frank M and Röhl U 2010 Plio-Pleistocene trends in ice rafted debris on the Lomonosov Ridge Quaternary International 219 168-176 doi:101016/jquaint200908010

[52] O'Regan M, Jakobsson M, Kirchner N 2010 Glacial geological implications of overconsolidated sediments on the Lomonosov Ridge and Yermak Plateau Quat. Sci. Rev. 29(25-26) 3532-3544 doi:101016/jquascirev201009009

[53] Haley A B, Frank M, Spielhagen R F and Eisenhauer A 2008 Influence of brine formation on Arctic Ocean circulation over the past 15 million years Nat. Geosci. 1 68-72 